\title{
Water from Air Production System based on Solar Energy in Egypt
}

\author{
Hanaa M. Farghally, Ninet M. Ahmed, Abd El-Shafy A. Nafeh, Faten H. Fahmy, Amal A. Hassan, Emaad A. \\ Sweelem
}
Photovoltaic Cells Department Electronics Research Institute, National Research Center Building, Dokki, Giza, 12622 Egypt

Received: October 14, 2020. Revised: November 8, 2020. Accepted: December 7, 2020. Published: December 14, 2020.

\begin{abstract}
Fresh water supplies are among the most limiting conditions in arid regions. Drinking water shortage is chronic, acute and widespread in North Africa, the Middle East and South Asia. The extraction of fresh water from the atmosphere has been adopted and developed as a new technology to provide water in remote areas. This paper concentrates on the extracting of potable water from air in remote areas using solar energy. A theoretical study for extracting water from atmospheric air is presented and performance of water production system based on standalone PV system was simulated and evaluated for two sites in Egypt; namely, Hurghada and Khargha Oasis. The unit extracts water by using solar thermal energy as the heating source for air and solar photovoltaic energy for supplying water production system driven fan. Perturb and observe (P\&O) method for maximum power point tracking (MPPT) has been designed and simulated for the proposed PV system. A Mathematical and simulation models using MATLAB/ SIMULINK software have been developed for evaluating the performance of the proposed system. The effect of climate conditions; ambient temperature and solar radiation on the PV system output power based on P\&O controller was also demonstrated. It was found that more amount of water from atmosphere can be extracted from densely humid and highly solar radiation regions.
\end{abstract}

Keyword - Atmospheric air, MPPT control, Solar energy, Water production.

\section{INTRODUCTION}

Water is the most important component of maintaining life after air. It is the heart of sustainable development, and is essential for socio-economic development, energy and food production and human survival. It is considered one of the most important natural resources to which the issue of food security depends and on which humanity depends. Rapid population growth and the development of urban areas and new communities have increased the demand for fresh water.
The problem of water scarcity is serious in arid regions and many countries. This necessitates the continuous development and improvement of all existing desalination methods and the evaluation of new technologies. The problem of supplying arid regions with fresh water can be solved in the following ways [1]; Transferring water from other sites, desalinating saline water and extracting water from air air [2], [3], [4]. However, transporting water to these areas is usually very costly, and desalination depends on the presence of saline water resources, which are usually scarce in dry areas [5]. Research provides a new and affordable way to extract fresh water from the Earth's atmosphere. The proposed method is fundamentally different from all current methods of water production. This method does not require transporting fresh water over long distances, it is inexpensive and environmentally friendly [6], [7]. Atmospheric air contains about 14,000 cubic kilometers of water in the form of steam [8], [9], [10], [11] and thus it can be used as a new and renewable water source. Water can be extracted from atmospheric air in two different ways. The first method is to cool the moist air to a temperature below the dew point of the air. The second method is to absorb water vapor from moist air using a solid or liquid desiccant, with the subsequent recovery of the extracted water by heating the dryer and condensing the evaporated water [8], [11].

the possibility of extracting water from the air is a recently studied activity, especially for the purpose of its production for emergencies or exceptional events, when drinking water is temporarily unavailable and in areas of war and deserts. It can be considered in remote locations, island resorts, mining sites, and situations where water scaling is a problem.

Among the renewable sources, solar energy is the leader. Features such as non-toxic, harmless and inexhaustible $\mathrm{CO} 2$ emission-free conversion and $\mathrm{CO} 2$ made this source very interesting [12]. Solar systems generally suffer from low efficiency and high costs. In order to overcome these shortcomings, maximum power must be extracted from the photovoltaic $(\mathrm{PV})$ system. The perturb and observation $(\mathrm{P} \& \mathrm{O})$ MPPT method is commonly used to maximize photovoltaic system power generation [3].

This paper presents the use of a standalone PV system for supplying the electrical power needed for electrical load of 
fresh water production system. At the same time, it presents the use of solar thermal energy for heating the inlet air to the fresh water production system. The $\mathrm{P} \& \mathrm{O}$ maximum power point tracking (MPPT) algorithm is also used to extract the available maximum power of the utilized PV array at different atmospheric conditions (ambient temperature and solar radiation). In addition the size of the utilized PV array is calculated. The proposed overall system (electrical \& thermal) is modelled and simulated using Matlab/Simulink. The simulation results of the system performance for two Egyptian sites; Hurghada city and Khargha Oasis are compared and discussed.

\section{LOCATION}

In this paper two sites located in Egypt, namely, Hurghada and Khargha Oasis are chosen as the sites under consideration. The climate parameters and the specific geographical location data for these locations were obtained from Egyptian solar radiation atlas [14]. Hurghada is located at latitude $27^{\circ} 17^{\prime} \mathrm{N}$ and longitude $33^{\circ} 46^{\prime} \mathrm{L}$. Whears, Khargha is located at latitude: $25^{\circ} 27^{\prime} \mathrm{N}$ and longitude $30^{\circ} 32^{\prime} \mathrm{L}$. The monthly solar radiations, relative humidity and average maximum \& minimum temperatures of Hurghada location are presented in Fig.1, Fig. 2 and Fig. 3 respectively. Also the monthly solar radiations, relative humidity and average maximum \& minimum temperatures for Khargha Oasis are presented in Fig.4, Fig. 5 and Fig. 6 respectively. The annual average solar radiation for Hurghada and Khargha Oasis locations are 6.38 $\mathrm{kWh} / \mathrm{m}^{2} / \mathrm{d}$ and $6.727 \mathrm{kWh} / \mathrm{m}^{2} / \mathrm{d}$ respectively.

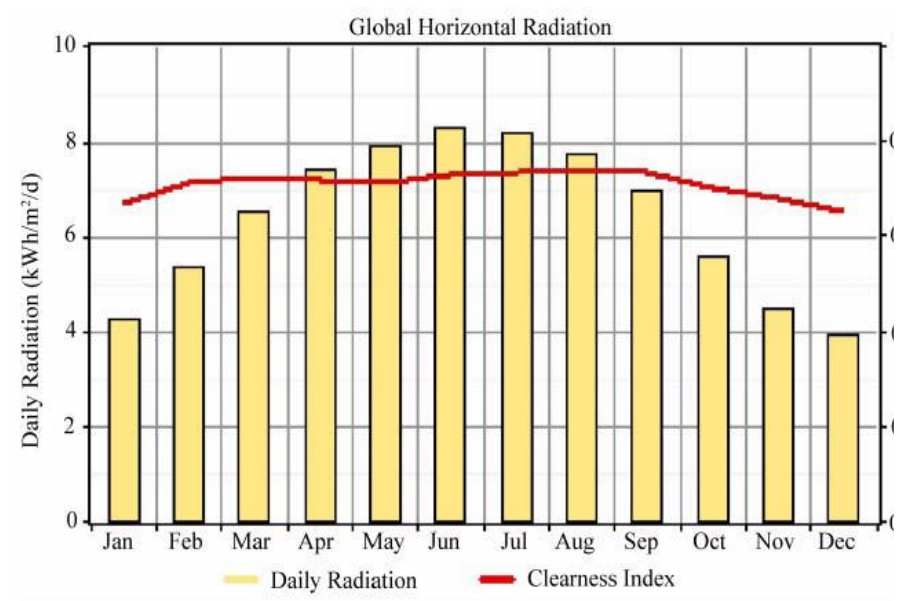

Fig. 1 Averages solar radiation profile for Hurghada city

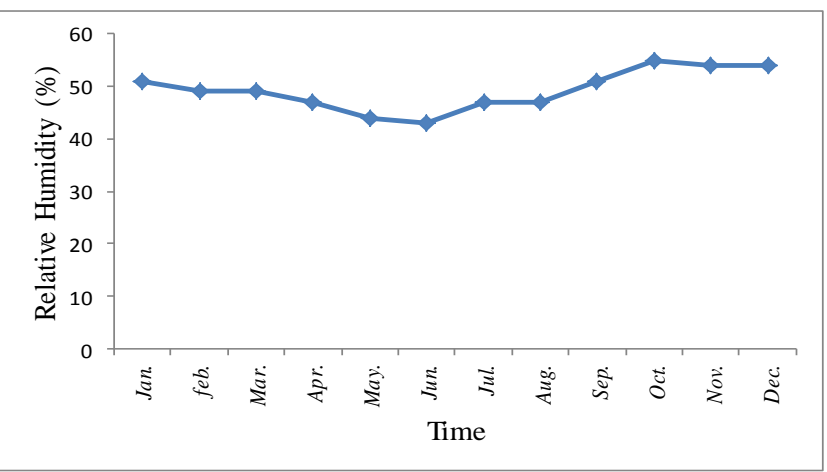

Fig. 2 Monthly Relative humidity profile for Hurghada city

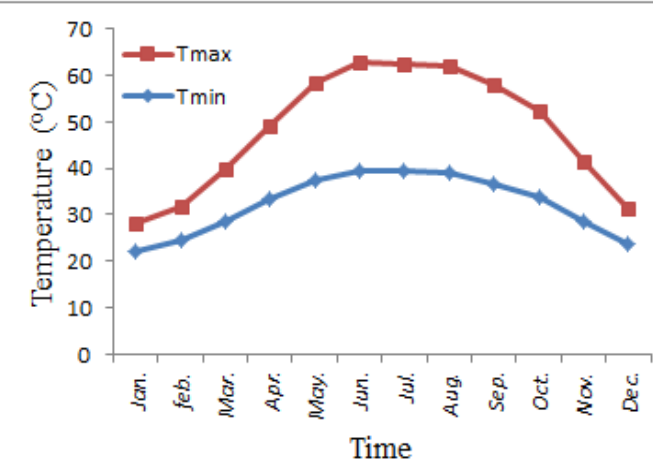

Fig. 3 Monthly maximum and minimum temperatures for Hurghada city

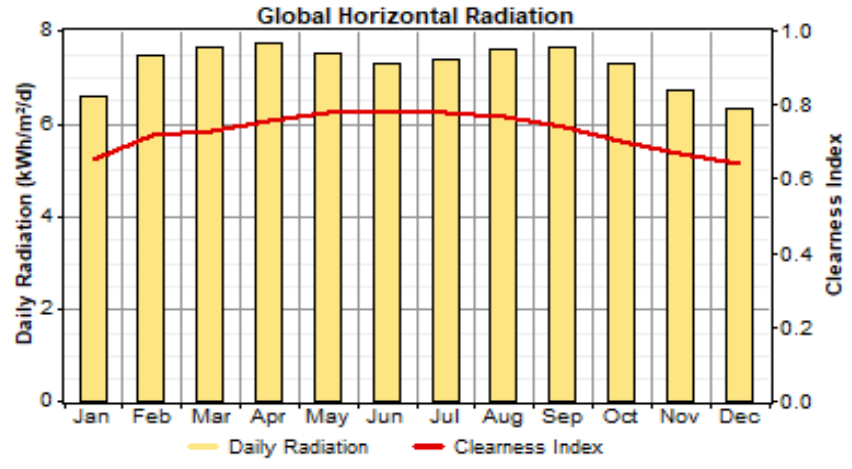

Fig. 4 Averages solar radiation profile for Khargha Oasis

\section{LOAD}

The electrical load is the daily energy consumption by the air driver DC fan of the fresh water production system. The fresh water production system is assumed to operate for 12 hours from 6:00 to 18:00 o'clock with a peak load of $60 \mathrm{~W}$ per water production system. 


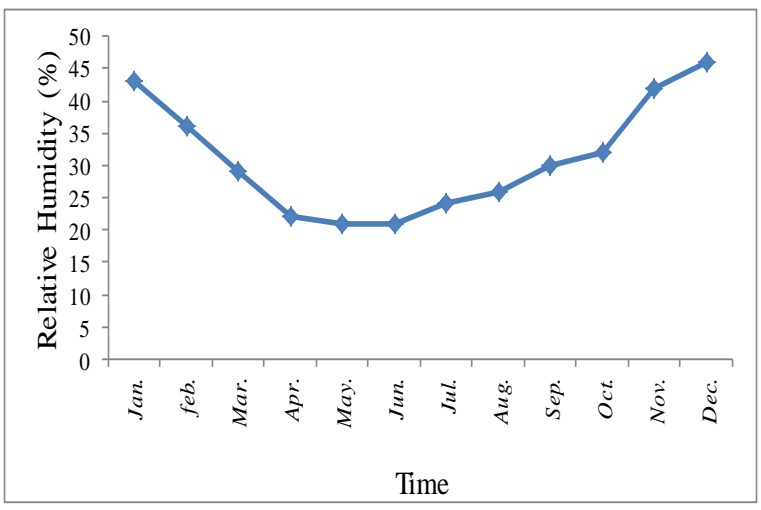

Fig. 5 Monthly Relative humidity profile for Khargha Oasis

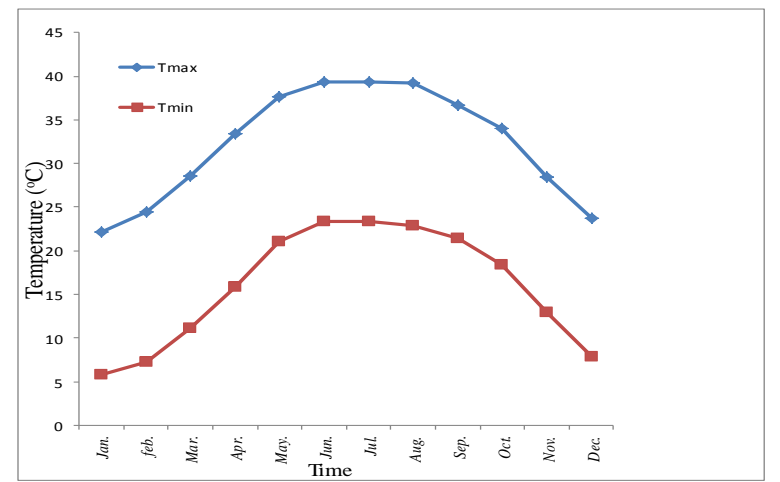

Fig.6 Monthly maximum and minimum temperatures for Khargha Oasis

\section{PROPOSED WATER PRODUCTION SYSTEM DESCRIPTION}

The block diagram of the overall water from air production system is presented in Fig. 7. It consists of two subsystems, the first one is thermal subsystem which consists of four components; solar air collector, DC fan, sorption bed and condenser. The second one is the electrical subsystem which consists of a PV array, a DC-DC converter and a MPPT controller.

\section{A. Thermal Subsystem}

\section{a. Air Thermal Collector}

The purpose of using air solar collectors is to raise the atmospheric air temperature to a temperature which can be used for various low and medium temperature applications. As the air passes through the solar collector, the heat that is gained by the sun's radiation will be transferred to the air thereby raising its temperature. There are several design configurations of solar air collectors which are currently used in different applications [15]. Flat plate collectors are the most common types of solar collectors and are usually used as solar hot water panels to generate hot water or as solar air heater for pre-heating the air in domestic or industrial heating applications. In this work the solar air collector is adopted to provide hot air to desorb the sorbents bed.

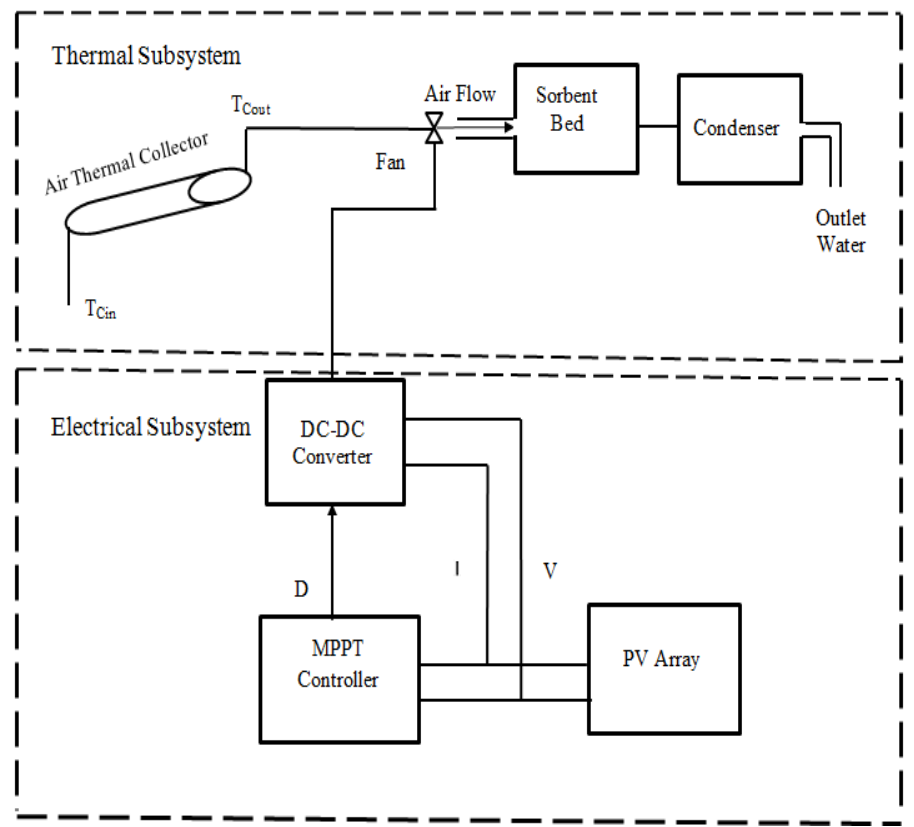

Fig.7 proposed water from air production system

b. Air Fan

A small DC forced air fan is utilized to push solar collector outlet air to the sorption and desorption processes.

\section{c. Sorption Bed and Condenser}

In desorption process, the sorbent bed is heated sufficiently by the hot air form solar collector and a lot of water vapour is released from the bed $[16,17]$. Then the air with high relative humidity flows into the condenser and the water vapor there condenses into liquid water, which is collected at the bottom of the condenser by gravity. Calcium chloride is a common (cheap and safe) desiccant that is widely used to extract water from moist air.

\section{B. Electrical Subsystem \\ a. PV Array Sizing}

Solar powered water production technology is the most environmentally friendly way to extract pure quality water from the air. PV array size is dependent on the energy load demand, specifications of the PV modules and site solar radiation. The PV modules used are Polycrystalline silicon with $30 \mathrm{Wp}$ maximum power. The details of solar module specifications are shown in Table 1 [18].

PV array must be sized to provide the required DC power to the electrical load of water production system.

Table 1: Specifications of PV module

\begin{tabular}{|c|c|}
\hline \multicolumn{2}{|c|}{ PV Array } \\
\hline Series Modules (NS) & 2 \\
\hline $\begin{array}{c}\text { Parallel Modules } \\
\text { (NP) }\end{array}$ & 1 \\
\hline Total Modules & 2 \\
\hline
\end{tabular}




\section{The number of series-connected modules $\left(N_{s}\right)$}

The DC operating voltage $\mathrm{V}_{\mathrm{S}}$ of the system is specified to be $24 \mathrm{~V}$. The number of modules Ns, which are to be connected in a series string, is directly determined by the DC operating voltage, as [19]:

$$
N_{S}=\frac{V_{S}}{V_{m p p}}
$$

Where $V_{m p p}$ is the nominal voltage of the module at STC.

\section{The number of parallel strings $\left(N_{p}\right)$}

This number is directly related to the power requirement of the load.

The typical energy requirement of the load EL (Wh/day) is calculated from the following equation [19]:

$$
\mathrm{E}_{\mathrm{L}}(\mathrm{Wh} / \mathrm{day})=P_{L} S H H_{\text {worstmonth }}
$$

Where PL (W) is the equivalent load power, $\mathrm{SHH}$ is the sunshine hours of the worst month $(=8.85 \mathrm{~h})$. The energy balance for a typical day can then be written as [19]:

$$
E_{L}(W h / \text { day })=P S H P_{\max } N_{s} N_{p}
$$

Where, in Eq. (3) the radiation incident on the panel is expressed in peak solar hours (PSH). Clearly, PSH is numerically equal to the irradiation in $\mathrm{kWh} / \mathrm{m}^{2}$ day [16]. Using equation (2), equation (3) gives the number of modules to be connected in parallel as [19]:

$$
N_{p}=\frac{E_{L}}{P S H P_{\max } N_{s}}
$$

Table 2: Sizing of photovoltaic array

\begin{tabular}{|c|c|}
\hline parameters & Values \\
\hline $\begin{array}{c}\text { Maximum power } \\
\left(\mathrm{P}_{\max }\right)\end{array}$ & $30 \mathrm{Wp}$ \\
\hline $\begin{array}{c}\text { Open circuit voltage } \\
\left(\mathrm{V}_{\mathrm{oc}}\right)\end{array}$ & $21 \mathrm{~V}$ \\
\hline $\begin{array}{c}\text { Maximum power } \\
\text { point voltage }\left(\mathrm{V}_{\mathrm{mp}}\right)\end{array}$ & $16.8 \mathrm{~V}$ \\
\hline $\begin{array}{c}\text { Short circuit current } \\
\left(\mathrm{I}_{\mathrm{sc}}\right)\end{array}$ & $1.94 \mathrm{~A}$ \\
\hline $\begin{array}{c}\text { Maximum power } \\
\text { point current }\left(\mathrm{I}_{\mathrm{mpp}}\right)\end{array}$ & $1.78 \mathrm{~A}$ \\
\hline
\end{tabular}

\section{b. DC/DC Boost Converter}

The use of a DC / DC converter is essential to realize MPPT, as it is the component, which is actuated by the controller in order to transmit the operating point of the PV source to be in sync with MPP. A boost converter and a resistive load are connected in parallel to the source. Fig. 8 shows the circuit of the DC/DC converter [20]. There are two modes for converter operation based on the MOSFET switch situation. The first one begins when the transistor is switched $\mathrm{ON}$, the current in the boost inductor increases linearly, and the diode is OFF state. The second one begins when the transistor is switched OFF; the energy stored in the inductor is released through the diode to the load. By varying the on/off time of MOSFET the power flow is controlled. The following relation describes the relation between input and output voltages [21].

$\mathrm{V}_{\mathrm{o}} / \mathrm{V}_{\mathrm{i}}=1 /(1-\mathrm{D})$

Where $\mathrm{Vi}$ is the PV output voltage, Vo voltage of boost converter, $\mathrm{D}$ is duty cycle, that can be expressed by the following equation [21].

$\mathrm{D}=\mathrm{T}_{\text {on }} / \mathrm{T}$

Where Ton is time when MOSFET is switched on, $\mathrm{T}$ is cycle period time. The time of the converter operation modes is controlled using plus width modulation signal (PWM). PWM operates at constant frequency i.e $\mathrm{T}$ is constant and Ton is varying, so $\mathrm{D}$ can be varied from 0 to1.

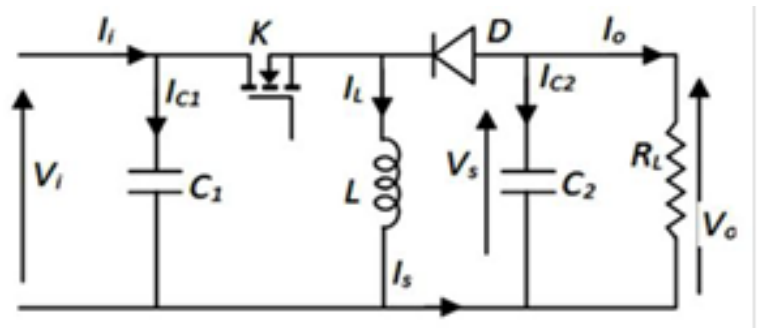

Fig. 8 Boost converter topology

\section{c. MPPT Controller}

Maximum power should be extracted from the PV panel using MPPT technique to optimize the efficiency of overall PV system. There are several methods and controllers that have been widely developed and implemented to track the MPP. The various MPPT techniques are perturb and observe (P\&O), incremental conductance (IC), artificial neural network, fuzzy logic, constant voltage, three point weight comparison, short current pulse, open circuit voltage. Perturb and observe $(\mathrm{P} \& \mathrm{O})$ method is dominantly used in practical PV systems for the MPPT control due to its simple implementation, high reliability, and tracking efficiency [21], 
[23], [24]. P\&O method applies perturbation to the buck-boost DC-DC converter by increasing or decreasing the pulse width modulator (PWM) duty cycle, subsequently observes the effect on the PV output power. If at any instant $t$ the output PV power $\mathrm{P}(\mathrm{t})$ \& voltage $\mathrm{V}(\mathrm{t})$ is greater than the previous computed power $\mathrm{P}(\mathrm{t}-1)$ \& $\mathrm{V}(\mathrm{t}-1)$, then the direction of perturbation is maintained otherwise it is reversed. The flow chart of algorithm has 4 cases as shown in Fig. 9 and can be explained as following:

When $\Delta \mathrm{P}<0 \& \mathrm{~V}(\mathrm{t})>\mathrm{V}(\mathrm{t}-1)$, this yields to $\mathrm{D}(\mathrm{t}+1)=\mathrm{D}(\mathrm{t})-\Delta \mathrm{D}$ When $\Delta \mathrm{P}<0 \& \mathrm{~V}(\mathrm{t})<\mathrm{V}(\mathrm{t}-1)$, this yields to $\mathrm{D}(\mathrm{t}+1)=\mathrm{D}(\mathrm{t})+\Delta \mathrm{D}$ When $\Delta \mathrm{P}>0$ \& $\mathrm{V}(\mathrm{t})<\mathrm{V}(\mathrm{t}-1)$, this yields to $\mathrm{D}(\mathrm{t}+1)=\mathrm{D}(\mathrm{t})-\Delta \mathrm{D}$ When $\Delta \mathrm{P}>0$ \&V(t) $>\mathrm{V}(\mathrm{t}-1)$, this yields to $\mathrm{D}(\mathrm{t}+1)=\mathrm{D}(\mathrm{t})+\Delta \mathrm{D}$

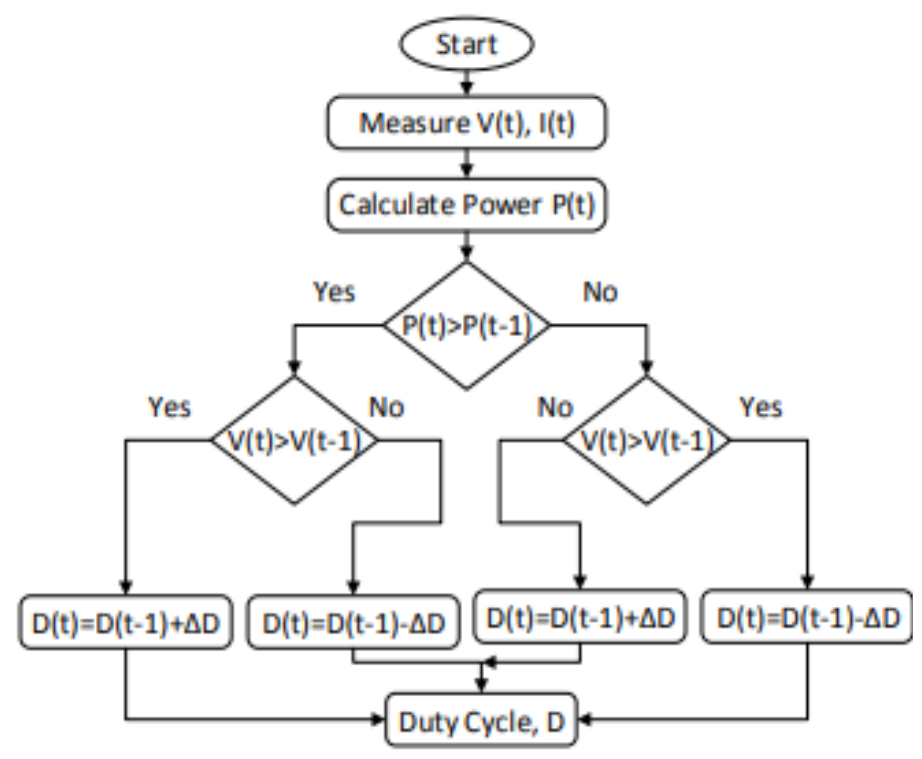

Fig. 9 Flowchart of P\&O MPPT algorithm

\section{SYSTEM MATHEMATICAL MODEL}

\section{A. PV Array Model}

The fundamental equations that describe the current-voltage (I-V) characteristic of the PV cell are as follows [25]:

$V_{D}=V+I R_{S}$

$I_{D}=I_{o}\left[\exp \left(\frac{V_{D}}{a \times V_{t}}\right)-1\right]$

$I=I_{p h}-I_{D}-\frac{V_{D}}{R_{p}}$

$I=I_{p h}-I_{o}\left[\exp \left(\frac{V_{p v+I R_{S}}}{\alpha \times V_{t}}\right)-1\right]-\frac{V_{p v+I R_{S}}}{R_{p}}$

Where $\mathrm{I}$ is the module current, $\mathrm{V}$ is the module voltage, $\mathrm{V}_{\mathrm{D}}$ is the voltage across the diode, $\mathrm{I}_{\mathrm{ph}}$ is the photo generated current, $I_{0}$ is the diode reverse saturation current, $R_{s}$ is the series resistance, $R_{p}$ is the shunt resistance, $\alpha$ is the diode ideality factor which depends on the PV technology, and $\mathrm{V}_{\mathrm{t}}$ is the junction thermal voltage and can be expressed as [25]:

$$
V_{t}=\frac{K T}{q}
$$

Where $\mathrm{k}$ is the Boltzmann's constant $\left(1.38 \times 10^{-23} \mathrm{~J} / \mathrm{K}\right)$, q is the electron charge $\left(1.602 \times 10^{-19} \mathrm{C}\right)$, and $\mathrm{T}$ is the temperature of the p-n junction in degrees Kelvin.

\section{B. Solar Collector Model}

The theoretical model used to study solar air collector that works in non-stationary regime is described by the balance Eq.

(12) [26]:

$\dot{Q_{U}}=I_{o}-\dot{Q_{p}}$

Where, $Q_{u}$ is the heat output of collector $(\mathrm{kW}), I_{o}$ is the absorbed solar radiation, $(\mathrm{kW})$ and $Q_{p}$ is lost heat $(\mathrm{kW})$.

Heat output of collector is expressed by the balance Eq. (13):

$\dot{Q_{U}}=\dot{m} C_{P}\left(T_{a, \text { out }}-T_{a, \text { in }}\right)$

Where, $\dot{m}$ is the air mass flow rate $(\mathrm{kg} / \mathrm{s}), C_{p}$ is the air specific heat at constant pressure $(\mathrm{kJ} / \mathrm{kg} \cdot \mathrm{K})$ and can be calculated using Eq. (14).

$C_{P=0.97034}+0.6789 \cdot 10^{-4} T+1.657 \cdot 10^{-7} T^{4}-$ $6.786 \cdot 10^{-11} T^{3}$

Where, $T_{a, \text { in }}$ is the air temperature at collector inlet $(\mathrm{K}), T_{a, \text { out }}$ is the air temperature at collector outlet $(\mathrm{K})$.Solar radiation absorbed by collector is given by Eq. (15).

$I_{o}=\eta_{o} . I \cdot A_{C}$

Where, $\eta_{o}$ is the optical efficiency, $I$ is the solar radiation $\left(\mathrm{kW} / \mathrm{m}^{2}\right)$ and $A_{c}$ is the area of collector absorber $\left(\mathrm{m}^{2}\right)$. Lost heat is described by the following equation:

$Q_{P}=U_{C}\left(T_{p, \text { med }}-T_{a m b}\right) A_{C}$

Where, $U c$ is the coefficient heat losses by convection $\left(\mathrm{kW} / \mathrm{m}^{2} \mathrm{~K}\right), T p$, med is the average temperature of collector $(\mathrm{K})$ and $T_{a m b}$ is the ambient average temperature $(\mathrm{K})$. Equation (12) can be re-written using the Eqs. (13)- (16) as:

$\dot{m} \dot{C}_{P}\left(T_{a, \text { out }}-T_{a, \text { in }}\right)=\eta_{o} . I \cdot A_{C}-U_{C}\left(T_{p, \text { med }}-T_{a m b}\right) A_{C}$

\section{Fan Model}

Power $=($ Volume $/$ Time $) *$ Density $*$ Specific Heat $*$ Temperature Rise 
In most applications the excess power (inefficiency of the system) is known and the airflow (volume/time) is unknown. Thus, the equation can be arranged as shown below [27].

Air flow $=$ Power $/($ Density $*$ Specific Heat $*$ Temperature Rise)

This equation is commonly written as:

$\mathrm{Q}=[\mathrm{q} /(\rho * \mathrm{Cp} * \Delta \mathrm{T})] * \mathrm{k}$

Where

Q: is the air flow

$\mathrm{q}:$ is the heat to be dissipated

$\rho$ : is the density of the air

$\mathrm{C}_{\mathrm{p}}$ : is the specific heat of the air

$\Delta \mathrm{T}$ : is the temperature the air will rise when absorbing the heat to be dissipated

$\mathrm{k}$ : is a constant value, dependent upon the units used in the other parameters
The most commonly used measure of humidity is relative humidity. Relative humidity can be simply defined as the amount of water in the air relative to the saturation amount the air can hold at a given temperature multiplied by 100 .

Absolute humidity or water vapour density is defined as [6], [8]:

$\mathrm{dv}=\mathrm{Mw} / \mathrm{V}\left(\mathrm{kg} \mathrm{m}^{-3}\right)$

Where $\mathrm{Mw}$ is mass of water vapour $(\mathrm{kg})$ and $\mathrm{V}$ is total volume of a moist air sample $\left(\mathrm{m}^{3}\right)$.

Potential water production rate (in $1 / \mathrm{d}$ ) is the daily water volume $\left(1\right.$ day $\left.^{-1}\right)=$ Air flow $\left(\mathrm{m}^{3} \mathrm{~s} \mathrm{~s}^{-1}\right) \times 86,400 \mathrm{~s}$ day

${ }^{1} \times$ Absolute humidity $\left(\mathrm{g} \mathrm{m}^{-3}\right) \times 1 / 1000 \mathrm{~g}^{-1} \times \eta$

\section{SYSTEM SIMULATION}

The simulation of the water production system is implemented in the MATLAB SIMULINK environment using the mathematical modeling and sizing parameters. The MATLAB-SIMULINK block diagram is shown in Fig. 10.

\section{Relative Humidity}

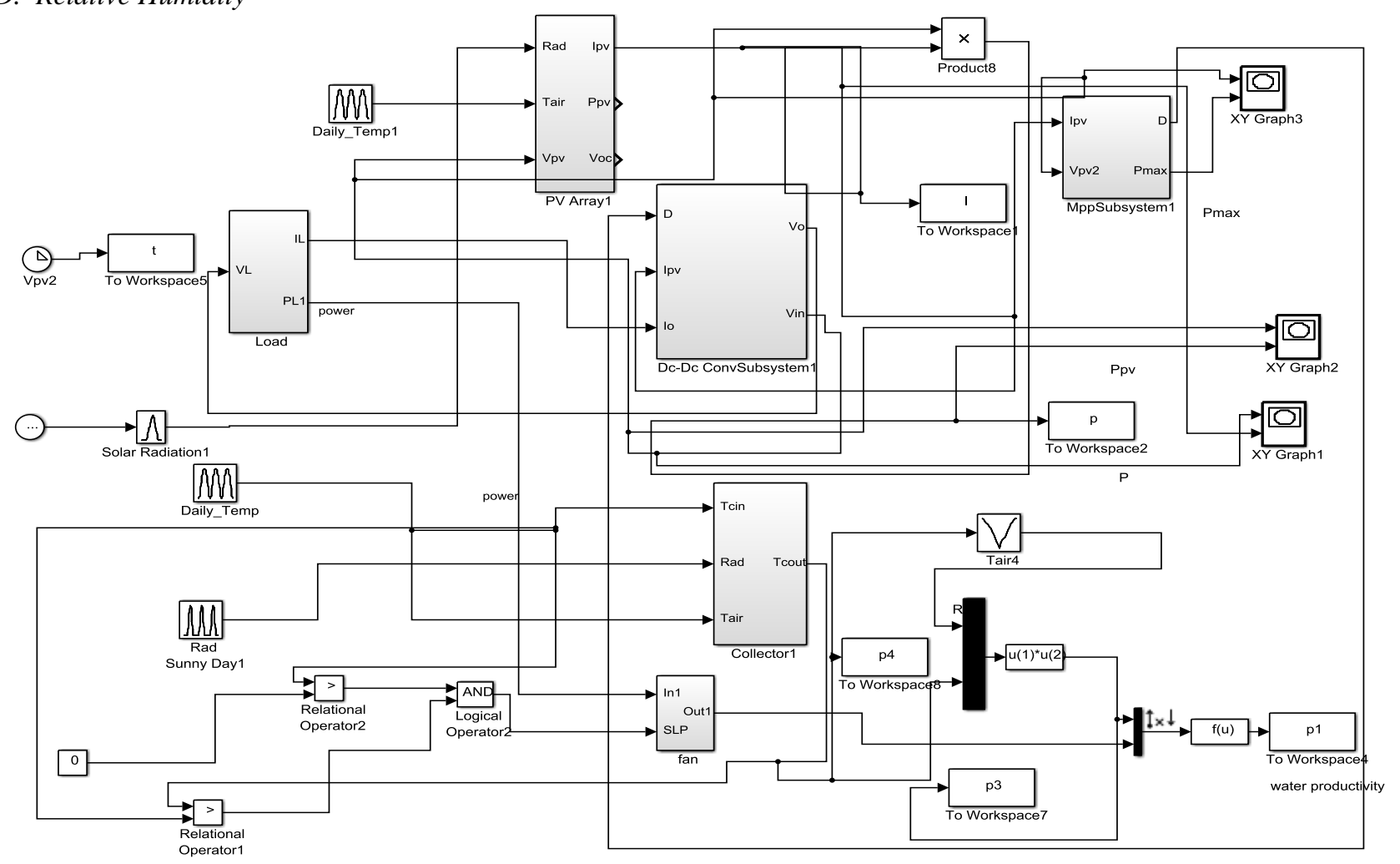

Fig.10 Simulink block diagram of water production system

\section{RESULTS AND DISCUSSIONS}

A comparison of the simulation results is made between two region of different climate conditions; Hurghada city and Khargha Oasis. The hourly variation of the thermal collector outlet air temperature, absolute humidity and water productivity of these regions for typical two days in winter and summer are investigated.

Fig. 11 and Fig. 12 describe the hourly variation of thermal collector outlet air temperature of Hurghada city for summer and winter day respectively. The collector outlet air 
temperature increases gradually and reaches its maximum value nearly at noon then decreases again at the end of the day. The behaviour of the collector outlet air temperature during the two days follows the behaviour of ambient temperature. Fig. 13 and Fig.14 illustrate the variation of absolute humidity with time of Hurghada city for two days (summer and winter) in the year. It can be observed that the absolute humidity in summer day is higher than that in winter. Also, as the absolute humidity increases the amount of water vapour increases and consequently the amount of the produced water increases as depicted in Fig15 and Fig16. The sorbents release a lot of water vapour due to the solar radiation and the total runtime of desorption reaction is about $10 \mathrm{~h}$, As indicated in Fig. 15, the water begins to be condenses at 08:00 and increase nearly abruptly to about $0.85 \mathrm{~L}$ at this time , then begin to increase gradually tile 14:00 and rich a maximum value of $1.35 \mathrm{~L}$, after that, a gradually decrease in the amount of condensed water tile 17:00. After 17:00, the mass water condensation reduces quickly to 0 , which means that the desorption process is basically completed and no more water can be collected after that. As the Absolute humidity and solar intensity in winter day is less than that of summer, the extracted quantity of water is less than that extracted in summer day as indicated in Fig. 16 and the maximum amount of water extracted is $0.8 \mathrm{~L} /$ hour at 15:00. It can be observed that the trend of water productivity follows that of solar radiation intensity.

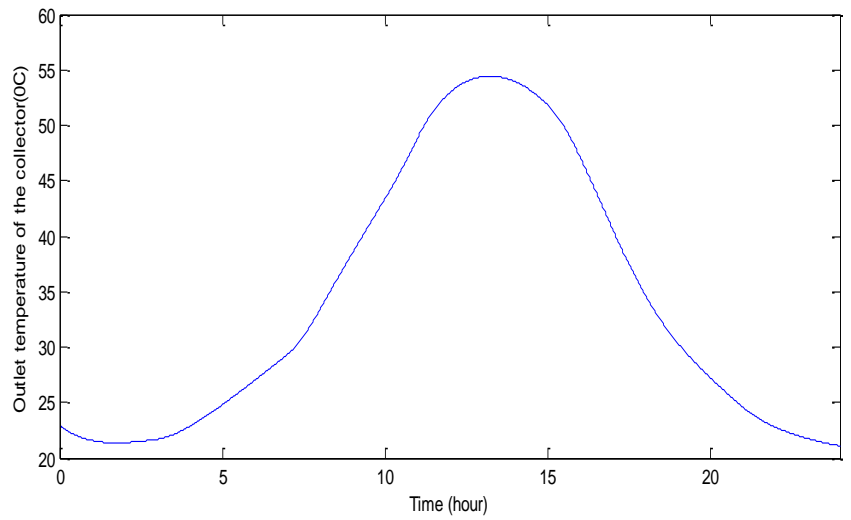

Fig.11 Hourly variation of collector outlet air temperature of Hurghada for summer day

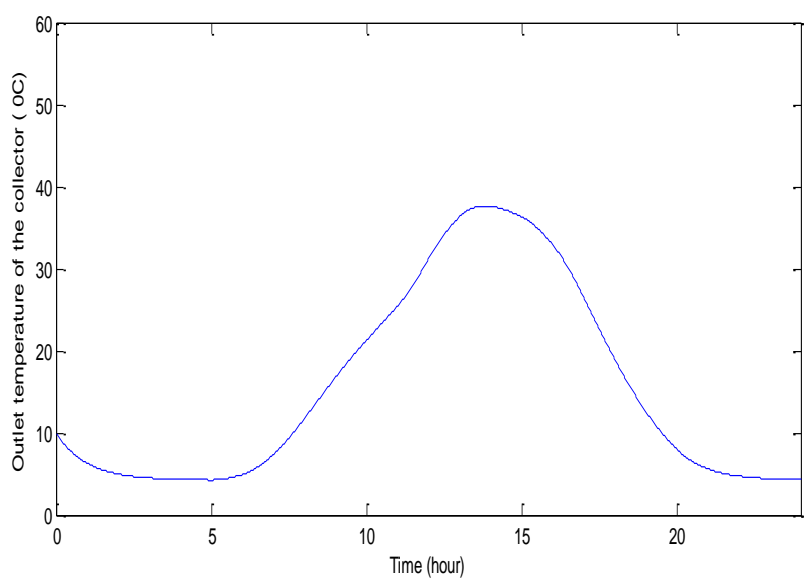

Fig.12 Hourly variation of collector outlet air temperature of Hurghada for winter day

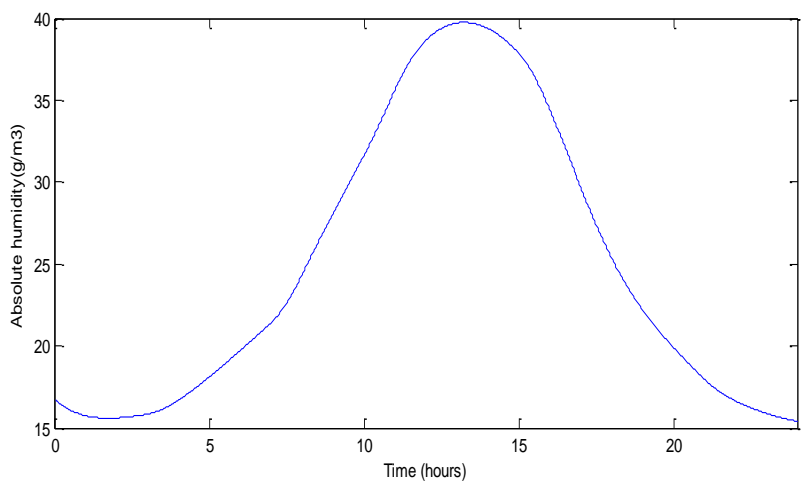

Fig.13Hourly variation of absolute humidity of Hurghada for summer day

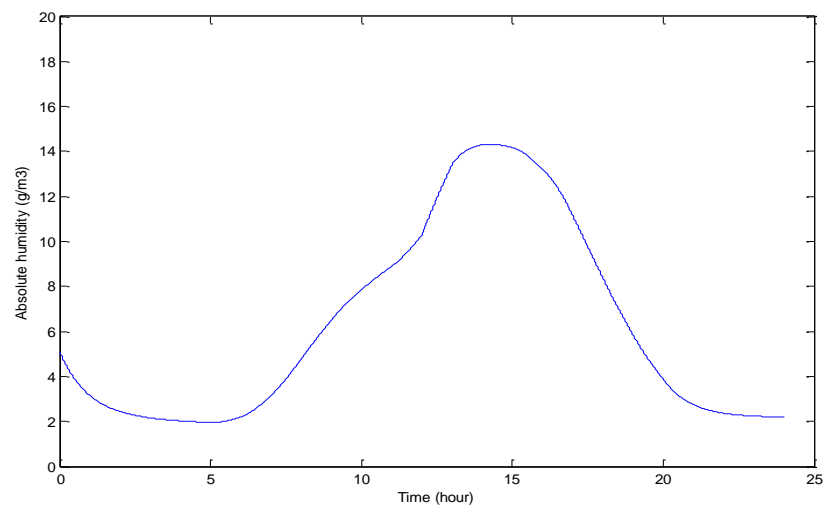

Fig.14 Hourly variation of absolute humidity of Hurghada for winter day 


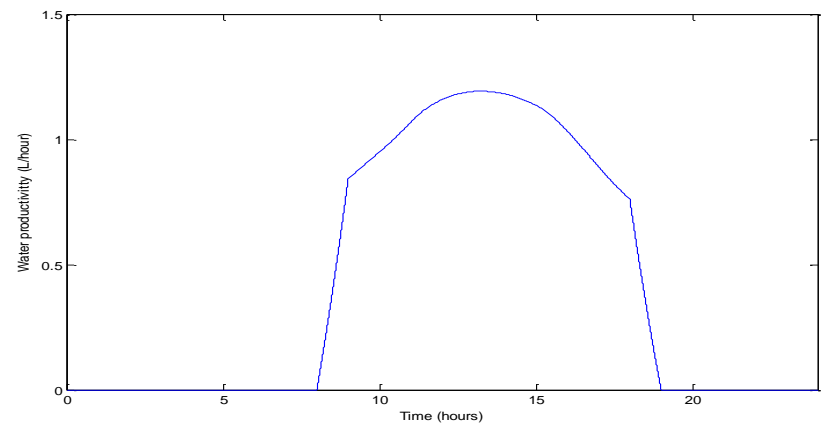

Fig.15 Hourly variation of water productivity of Hurghada for summer day

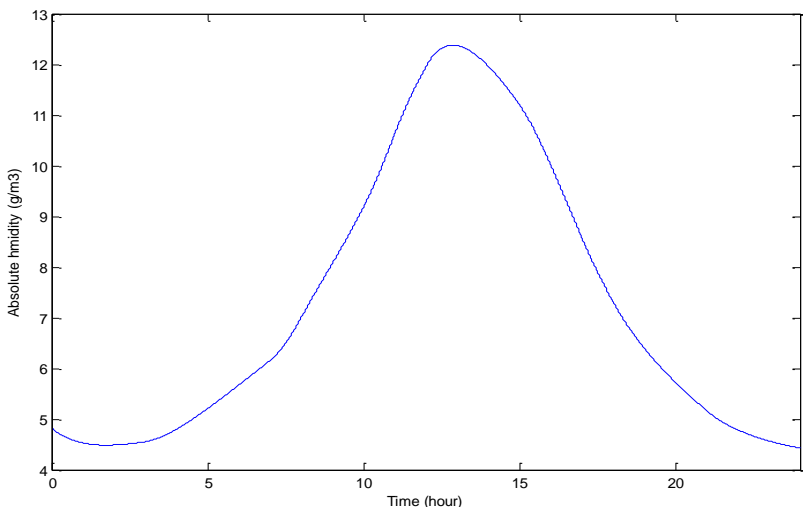

Fig. 16 Hourly variation of water productivity of Hurghada for winter day

Thermal collector outlet air temperature of Khargha Oasis for summer and winter day is illustrated in Fig. 17 and Fig. 18 respextively. Thermal collector outlet Air temperature in summer is higher than that in winter._Fig. 19 and Fig.20 illustrates the variation of absolute humidity with time for Khargha Oasis. It can be found that the climate of Khargha Oasis is drying compared with that of Hurghada city. Therefore the rate of water productivity of khargha Oasis is less than that obtained from Hurghada city as shown in Fig. 21 and Fig. 22.The maximum amount of water extracted from air is $0.35 \mathrm{~L} /$ hour at 13.00 and is $0.45 \mathrm{~L} /$ hour at 13.30 for summer and winter day respectively.

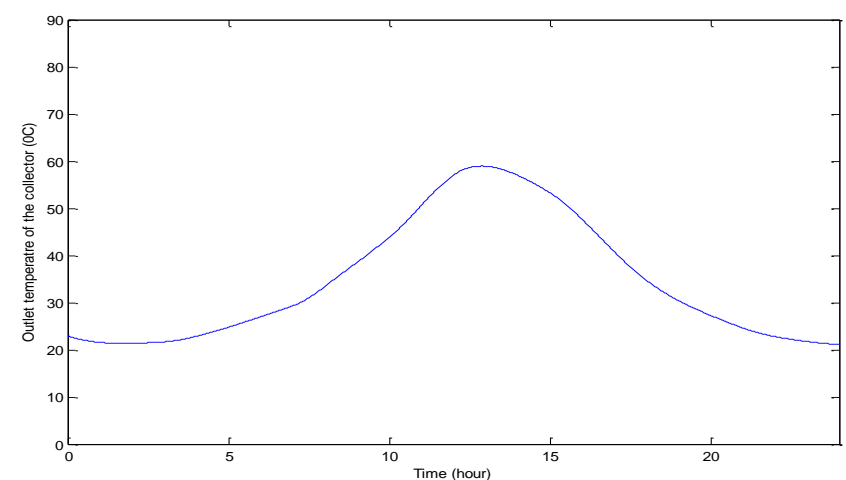

Fig. 17 Hourly variation of thermal collector outlet air temperature of Khargha Oasis for summer day

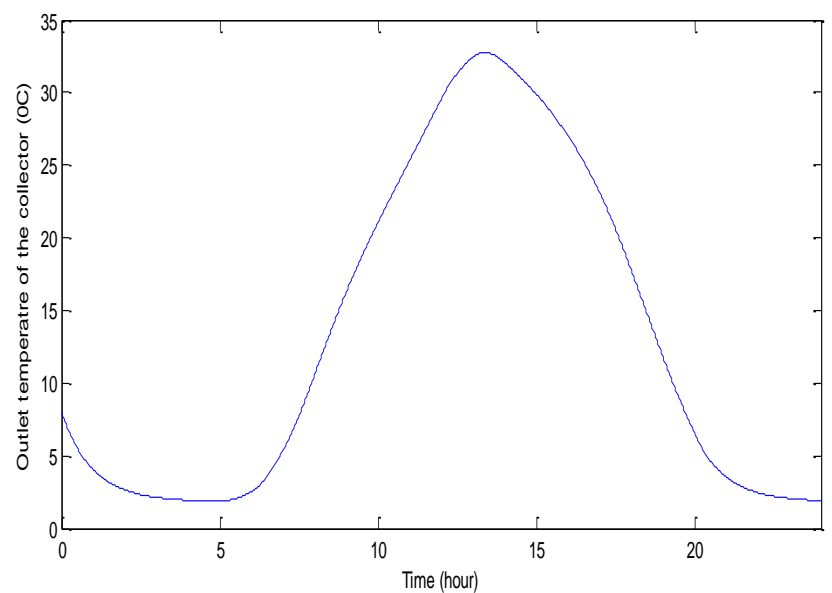

Fig.18 Hourly variation of thermal collector outlet air temperature of Khargha Oasis for winter day

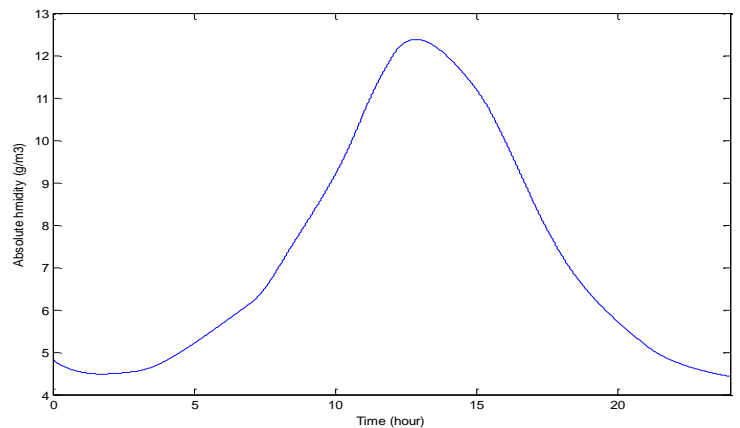

Fig.19 Hourly variation of absolute humidity of Khargha Oasis for summer day 


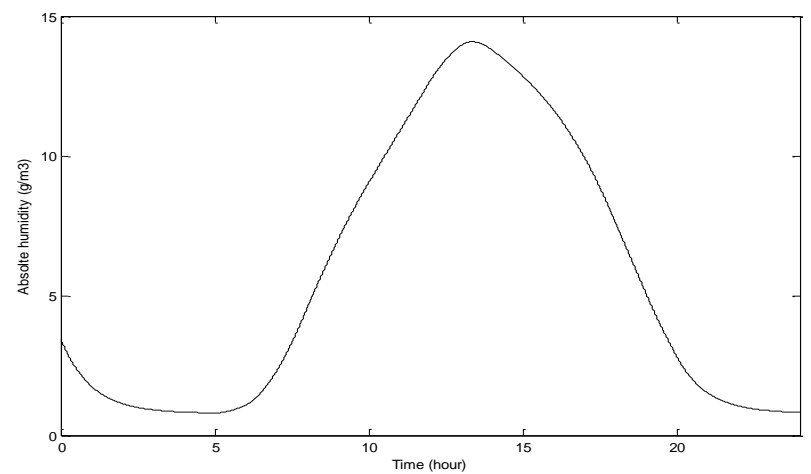

Fig.20 Hourly variation of absolute humidity of Khargha Oasis for winter day

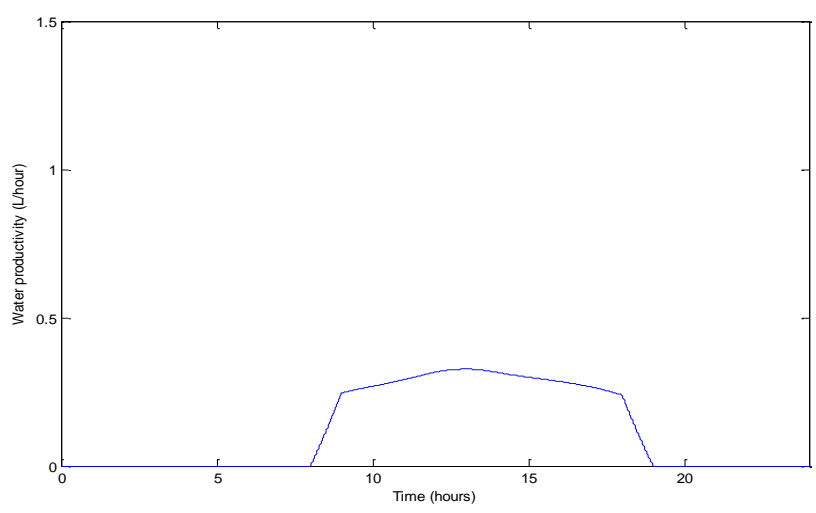

Fig. 21 Hourly variation of water productivity of Khargha Oasis for summer day

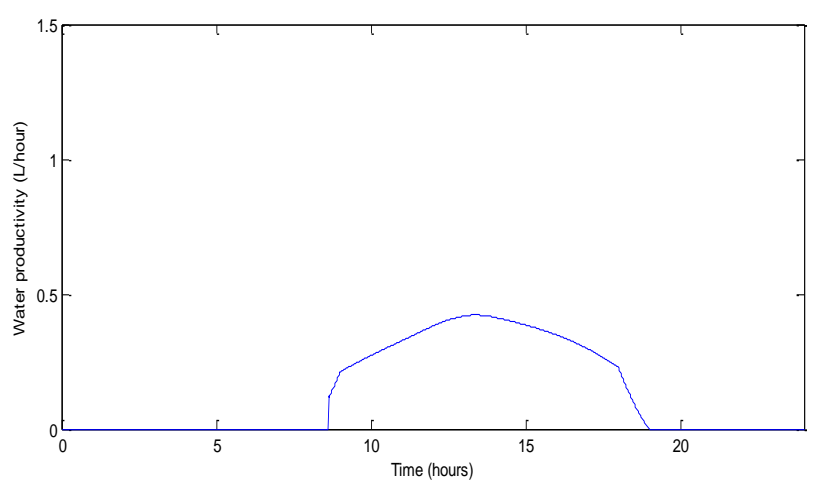

Fig. 22 Hourly variation of water productivity of of Khargha Oasis for winter day

Fig. 23 shows the PV array output power at standard test condition of $1000 \mathrm{~W} / \mathrm{m}^{2}$ and of $25^{\circ} \mathrm{C}$. The PV array output power under test conditions is $60 \mathrm{~W}$.

The performances of proposed P\&O MPPT algorithm have been evaluated at $1000 \mathrm{~W} / \mathrm{m}^{2}$ and $25^{\circ} \mathrm{C}$. The time response of $\mathrm{P} \& \mathrm{O}$ algorithm is less than $1 \mathrm{~ms}$ and it produces small overshoot as showed in Fig. 24.

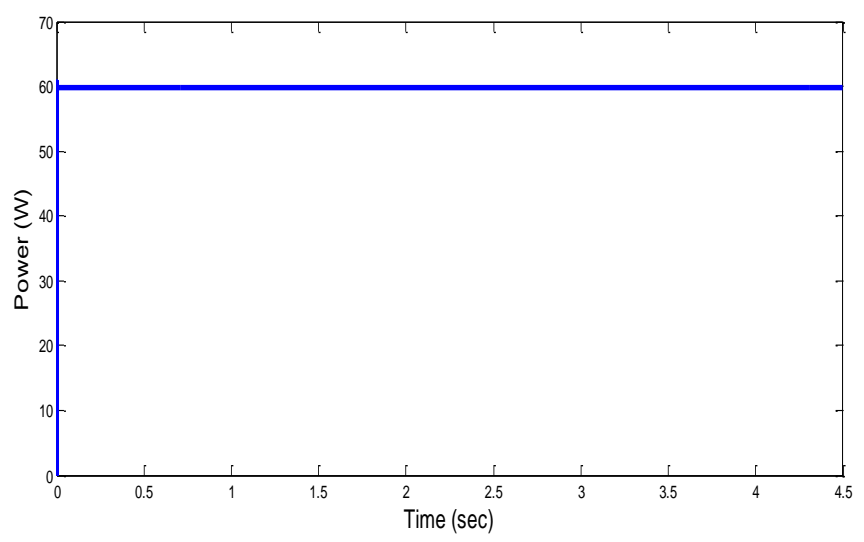

Fig. $23 \mathrm{PV}$ array output power under $1000 \mathrm{~W} / \mathrm{m}^{2}$ and $25^{\circ} \mathrm{C}$

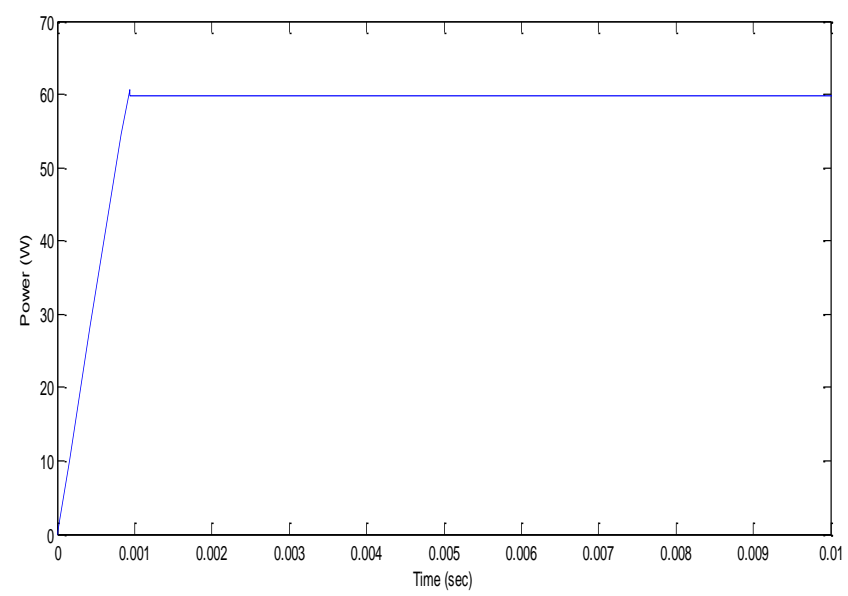

Fig. 24 $\mathrm{P} \& \mathrm{O}$ algorithm time response of $\mathrm{PV}$ array output power under $1000 \mathrm{~W} / \mathrm{m}^{2}$ and $25^{\circ} \mathrm{C}$

The output power of PV array is quite dependent on the environmental and operational conditions, among all the factors affecting the output power of a PV array are ambient temperature, and solar radiation. Therefore, the proposed $\mathrm{P} \& \mathrm{O}$ MPPT is tested for sudden increase and sudden decrease of ambient temperature and solar radiation.

Fig. 25 and Fig. 26 show the performance of the PV output power at constant temperature of $25^{\circ} \mathrm{C}$ and at sudden increase $\left(500 \mathrm{~W} / \mathrm{m}^{2}, 750 \mathrm{~W} / \mathrm{m}^{2} 1000 \mathrm{~W} / \mathrm{m}^{2}\right)$ and decrease $\left(1000 \mathrm{~W} / \mathrm{m}^{2}\right.$, $750 \mathrm{~W} / \mathrm{m}^{2}$ and $500 \mathrm{~W} / \mathrm{m}^{2}$ ) of solar radiation respectively. The decrease of the solar radiation implies a decrease of the PV output power. The obtained power for different illumination levels of 500,750 and $1000 \mathrm{~W} / \mathrm{m}^{2}$ are 30,45 and $60 \mathrm{~W}$ respectively. 


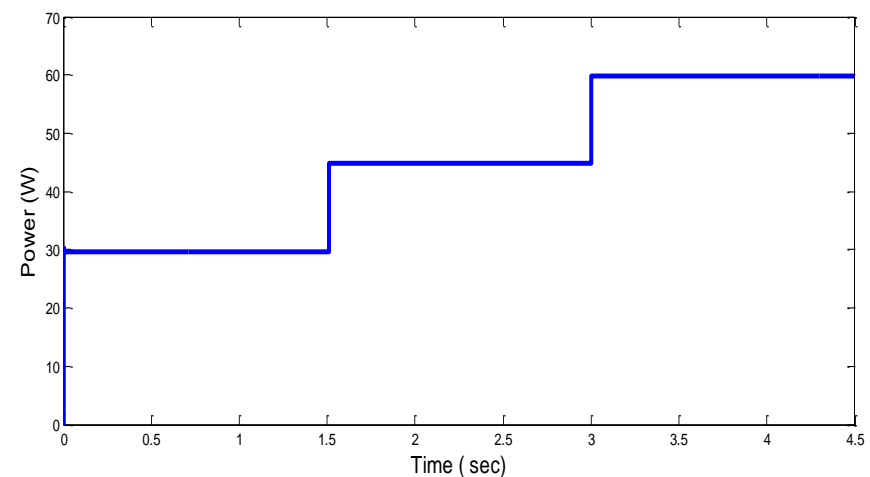

Fig. 25.Change in the output power of the PV system due to sudden increase in the solar radiation

Fig. 27and Fig. 28 show the response of the PV output power at constant solar radiation of $1000 \mathrm{~W} / \mathrm{m}^{2}$ and at sudden increase $\left(25^{\circ} \mathrm{C}, 50{ }^{\circ} \mathrm{C}\right.$ and $\left.75{ }^{\circ} \mathrm{C}\right)$ and decrease $\left(75^{\circ} \mathrm{C}, 50{ }^{\circ} \mathrm{C}\right.$ and $25{ }^{\circ} \mathrm{C}$ ) in temperature, respectively. The increase of temperature implies a decrease of the PV output power. The obtained power for different temperature levels of $25{ }^{\circ} \mathrm{C}, 50$ ${ }^{\circ} \mathrm{C}$ and $75{ }^{\circ} \mathrm{C}$ are 60,56 and $45 \mathrm{~W}$ respectively.

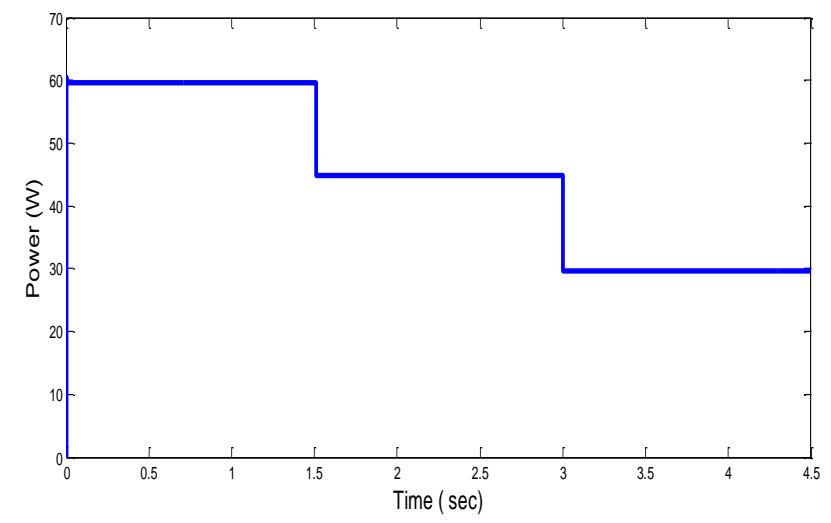

Fig. 26.Change in the output power of the PV system due to sudden decrease in the solar radiation

The simulation results for solar radiation and temperature (environmental conditions change) variations show that the proposed $\mathrm{P} \& \mathrm{O}$ MPPT technique provides a good tracking speed at fast changing of solar radiation and ambient temperature.

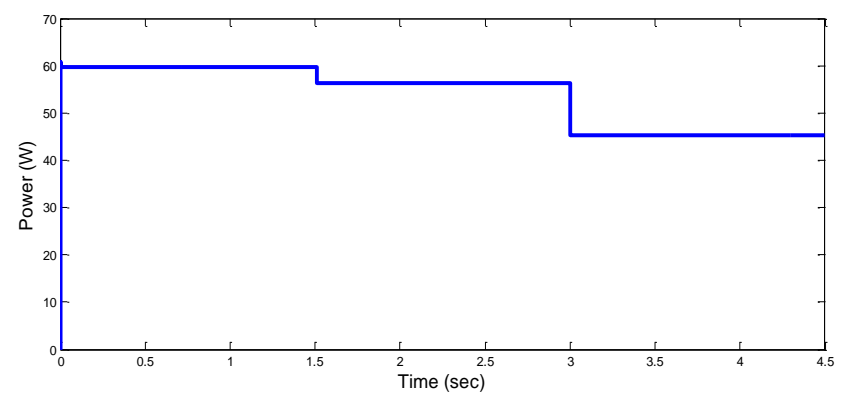

Fig.27 Change in the output power of the PV system due to sudden increase in the ambient temperature

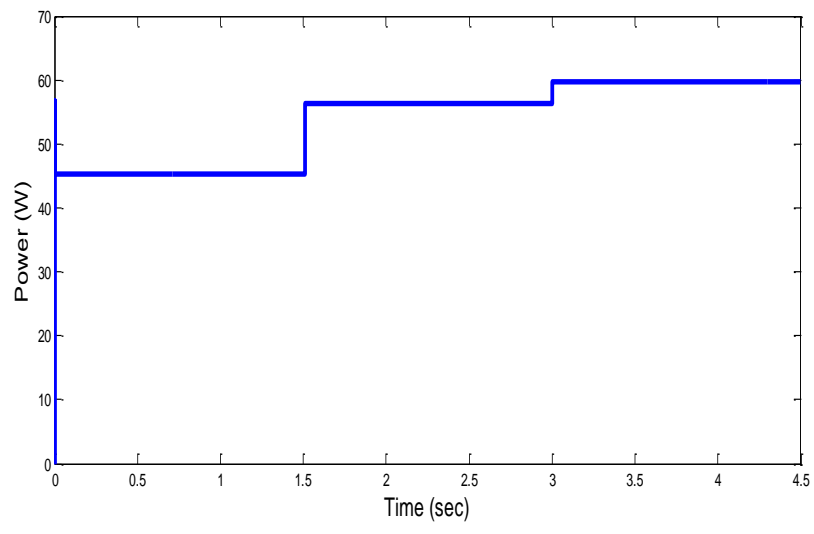

Fig. 28 Change in the output power of the PV system due to sudden decrease in the ambient temperature.

\section{CONCLUSION}

For investigating the effects of climate parameters changes on the quantity of water extracted from air, two main sites in Egypt, namely; Hurghada city in red sea and Khargha Oasis in western desert are selected as the sites under consideration. A study to evaluate the process of water extraction from air has been performed for typical two days in summer and winter.

Perturb and observe (P\&O) method for maximum power point tracking (MPPT) of photovoltaic (PV) system is developed for water production system.

Simulations results verified that the operating point of PV system operate closer to a maximum power point for variations in solar radiation and temperature. The daily estimated water yield for Hurghada city is higher than that for Khargha Oasis. Maximum amount of water extracted from air is $1.2 \mathrm{~L} /$ hour at $13: 30$ at maximum solar radiation in summer day. Also, in winter day, maximum amount of water extracted from air is $0.8 \mathrm{~L} /$ hour at 13:30. The obtained results represent opportunities to obtain a new water resource to supply fresh water to water-poor communities in Egyptian regions as one option for small scale locally managed water supplies

\section{References}

[1] Kobayashi, M., 1963. A method of obtaining water in arid lands. Solar Energy, 7(3), pp.93-99.

[2] Ahmadi, E., McLellan, B., Mohammadi-Ivatloo, B. and Tezuka, T., 2020. The Role of Renewable Energy Resources in Sustainability of Water Desalination as a Potential Fresh-Water Source: An Updated Review. Sustainability, 12(13), p.5233.

[3] A. Magrini, L. Cattani, M. Cartesegna, L. Magnani, "Water production from air conditioning systems: some evaluations about a sustainable use of resources", Sustainability, vol. 9, pp. 1-17, 2017.

[4] Elashmawy, M., 2020. Experimental study on water extraction from atmospheric air using tubular solar still. Journal of Cleaner Production, 249, p.119322. 
[5] Habeebullah, B., 2020. Potential Use Of Evaporator Coils For Water Extraction In Hot And Humid Areas. B. A.

[6] El-Ghonemy, A., 2012. RETRACTED: Fresh water production from/by atmospheric air for arid regions, using solar energy: Review. Renewable and Sustainable Energy Reviews, 16(8), pp.6384-6422.A.M.K..

[7] Madhu, B., Balasubramanian, E., Nagarajan, P., Sathyamurthy, R., Kabeel, A., Arunkumar, T. and Mageshbabu, D., 2017. Improving the yield of fresh water from conventional and stepped solar still with different nanofluids. Desalination and Water Treatment, 100, pp.243-249.

[8] R. V. Wahlgren, "Atmospheric water vapour processor designs for potable water production: A Review", Water Research, vol. 35, Issue 1, pp. 1-22, January 2001.

[9] A. M. Hamed, A. A. Aly, E. B. Zeidan,"Application of solar energy for recovery of water from atmospheric air in climatic zones of saudi arabia", Natural Resources, Vol. 2, pp.8-17, 2011.

[10] J.Y. Wang, J.Y. Liu, R.Z. Wang , L.W. Wang, "Experimental investigation on two solar-driven sorption based devices to extract fresh water from atmosphere", Applied Thermal Engineering, vol. 127, pp.1608-1616, 2017.

[11] M.A. Talaat, M.M. Awad, E.B. Zeidan, A.M. Hamed, "Solar-powered portable apparatus for extracting water from air using desiccant solution", Renewable Energy, vol. 119, pp.662 - 674, 2018.

[12] H. Mahamudul, M. Saad, M. I. Henk, "Photovoltaic system modeling with fuzzy logic based maximum power point tracking algorithm", Hindawi Publishing Corporation, International Journal of Photoenergy, ID 762946, pp. 1-10, 2013. .

[13] A. Al Nabulsi, R. Dhaouadi, "Fuzzy logic controller based perturb and observe maximum power point tracking", in Proc. International Conference on Renewable Energies and Power Quality (ICREPQ'12), Santiago de Compostela (Spain), 28th - 30th March, pp. 1-6, 2012 .

[14] M. A. Mosalam Shaltout, "Egyptian solar radiation atlas," New and Renewable Energy Authority, Ministry of Electricity and Energy: United States Agency for International Development, 1991.

[15] M.A. Karim, Z.M. Amin, "Mathematical modelling and performance analysis of different solar air collectors" IIUM Engineering Journal, vol. 16, no. 2, pp. 43-55, 2015.

[16] Vinay M V, Suman A, Shadakshari R, "Dehumidification of atmospheric air for water production", International Journal of Innovative Research in Science, Engineering and Technology, Vol. 7, Issue 4, pp. 3808- 3813, April 2018.

[17] M. Elashmawy," Experimental study on water extraction form atmospheric air using tubular solar still", Journal of Cleaner Production, vol. 249, pp. 1-14, 10 March 2020

[18] 30W Photovoltaic module- 330J, Solar Electric Supply, Inc. May 2012, www.solarelectricsupply.com

[19] T. Markvart, "Solar Electricity", John Wiley \& Sons, LTD, 2000.
[20] H. Assem, F. Bouchafa, A. Hadj Arab and B. Bouzidi, "Fuzzy logic controller in optimizing of power management in stand-alone photovoltaic system", Revue des Energies Renouvelables SIENR'14 Ghardaïa, pp.41 48, 2014

[21] H.E.A. Ibrahim, Mahmoud Ibrahim," Comparison Between Fuzzy and P\&O Control for MPPT for Photovoltaic System Using Boost Converter", Journal of Energy Technologies and Policy, vol.2, no.6, pp .1-11, 2012.

[22] S. Karthika , P. Rathika, D. Devaraj, "Fuzzy logic based maximum power point tracking designed for $10 \mathrm{~kW}$ solar photovoltaic system", International Journal of Computer Science and Management Research, vol. 2 Issue 2, pp. 1421- 1427, February 2013.

[23] G. Sudhakar, J. S. Kumari, "Design and analysis of P\&O and FLC MPPT techniques for photovoltaic system", IRET Transaction on Power Electronics and Drives (ITPED) vol. 1, Issue. 1, pp. 17-23, Oct. 2013.

[24] N. Mohammad, M. A. Islam, T. IKarim, Q. D. Hossain, "Improved solar photovoltaic array model with FLC based maximum power point tracking", International Journal of Electrical and Computer Engineering (IJECE) vol.2, no.6, pp. 717-730, December 2012.

[25] E. Benkhelil, A. Gherbi, "Modeling and simulation of grid-connected photovoltaic generation system", Revue des Energies Renouvelables SIENR'12 Ghardaïa (2012), pp. $295-306$.

[26] L. S. Paraschiv, S. Paraschiv, I. V. Ion, "Experimental and theoretical analyses on thermal performance of a solar air collector", Environmental Engineering and Management Journal, vol.13, no. 8, pp.1965-1970, August 2014.

[27] http//www, "Understanding Airflow Fundamentals for Proper Dc Fan Selection”, www.cui.com.

\section{Creative Commons Attribution License 4.0 (Attribution 4.0 International, CC BY 4.0)}

This article is published under the terms of the Creative Commons Attribution License 4.0 https://creativecommons.org/licenses/by/4.0/deed.en US 